than that of the work on the same subject by Gough, but the authors no doubt feel bound to extend the data still further before attempting broad generalisations. Some account is given of the relation between fatigue and 'creep,' which is of undoubted importance, and deserves further study. Short chapters on the fatigue of wood and concrete are added, and there is an excellent bibliography. Text and diagrams are clearly printed.

$$
\text { C. H. D. }
$$

Fundamentals of Dairy Science. By Associates of Lore A. Rogers. (American Chemical Society Monograph Series, No. 41.) Pp. 543. (New York: The Chemical Catalog Co., Inc., 1928.) 5.50 dollars.

THIs is a very valuable monograph which presents an up-to-date account of the principles upon which the dairy industry is based, and brings together the results of much research that has been prosecuted in this field. The contributors are, or have been, members of the staff of the Research Laboratories of the Bureau of Dairy Industry of the United States Department of Agriculture, and included in the list are several well-known names.

Part I. deals with the constituents of milk, the chapters on the proteins and the milk fat being of particular interest; in the latter is included a summary of the methods used in the examination of milk fat. Part II, is devoted to the physical chemistry of milk and milk products; the influence of physical conditions upon the separation of milk, the making of butter; the coagulation of milk and the making of cheese are treated very fully.

Part III. deals mainly with the bacteriology of milk and milk products. The sources of the bacteria are explained, as well as the effects they produce and the factors which influence their growth. Part IV. starts with the nutritional value of milk and discusses the part which it plays in the feeding of young and adult animals. The part played by milk in regard to the requirements of the body for vitamins is also dealt with. The final chapter is devoted to the physiology of milk secretion, the influence of food upon milk production, and especially the part played by the protein and fat of the diet.

The volume is excellent in every way; its arrangement brings out the results of inquiries which have often been neglected in books on dairying, and the list of references at the end of each chapter will be found most helpful to workers on the subject.

Materialprüfung mit Röntgenstrahlen: unter besonderer Berücksichtigung der Röntgenmetallographie. Von Prof. Dr. Richard Glocker. Pp. vi +377. (Berlin: Julius Springer, 1927.) 31.50 gold marks.

There are now many text-books which deal with the examination of metals by means of X-rays, and the work of Prof. Glocker has many good features. It is excellently printed, and contains a full account of the various methods of obtaining X-ray spectra and of deducing from them the structure of metallic crystals.

The most modern types of X-ray tube are described, but the reader misses a discussion of the difficulties connected with their use, and a critical review of experimental methods. It is true that one worker will obtain good results with a form of apparatus with which another is entirely unsuccessful, but the reasons for differences in behaviour of different tubes have not, to the reviewer's knowledge, been examined in detail in a text-book. The subject of the examination of metals for defects by the absorption of X-rays is dealt with very briefly, and the main portion of the book is concerned with the determination of structure. The known data respecting space-lattices of metals and alloys are collected, whilst non-metallic substances only receive brief notice.

The most conspicuous defect is the almost complete neglect of English work, in a field in which this country has made such important discoveries. Even the work of the Braggs is only quoted from the comparatively elementary book by those authors, and not from original papers, and their collaborators are scarcely mentioned. As a review mainly of German work, however, the volume may be recommended as being both clear and thorough.

\section{Biologie der Früchte und Samen (Karpobiologie).} Von Prof. Dr. E. Ulbrich. (Biologische Studienbücher, herausgegeben von Walther Schoenichen, Band 6.) Pp. viii +230. (Berlin: Julius Springer, 1928.) 12 gold marks.

A HANDBOOK on the biology of fruits and seeds has long been needed. This work only partly supplies the need. While the morphological aspects are adequately dealt with, considering the size of the book, the biological data given are less satisfactory. This is largely due to the relative neglect of field investigation and experiment by the majority of those who have studied fruits and seeds. Many biologists cannot feel satisfied that opinions stated as a result of herbarium and museum studies are trustworthy accounts of what actually happens in Nature. It is certainly risky to conclude that morphological peculiarities function for wide dispersal in the absence of observational and experimental facts, and deductions from analogical resemblances may be entirely misleading.

Prof. Ulbrich divides the main part of his subject on the basis of the agents of dispersal. Selfdispersal (autochory) is first considered. Agents external to the plant result in allochory, of which the following types are recognised: zoochory (animal dispersal, endozoic, synzoic, epizoic), hydathochory (water dispersal), and wind dispersal (anemochory). Short accounts of polychory, polycarpy, and vivipary conclude the book. An adequate index is provided, but the list of literature is far from complete, especially for English research. The work is well illustrated with fifty-one textfigures. 